\title{
A novel solar-assisted ground-source heat pump (SAGSHP) with seasonal heat- storage and heat cascade utilization: field test and performance analysis
}

Article

Accepted Version

Creative Commons: Attribution-Noncommercial-No Derivative Works 4.0

Sun, T., Yang, L., Jin, L., Luo, Z., Zhang, Y., Liu, Y. and Wang, Z. (2020) A novel solar-assisted ground-source heat pump (SAGSHP) with seasonal heat-storage and heat cascade utilization: field test and performance analysis. Solar Energy, 201. pp. 362-372. ISSN 0038-092X doi:

https://doi.org/10.1016/j.solener.2020.03.030 Available at https://centaur.reading.ac.uk/89411/

It is advisable to refer to the publisher's version if you intend to cite from the work. See Guidance on citing.

To link to this article DOI: http://dx.doi.org/10.1016/j.solener.2020.03.030

Publisher: Elsevier

All outputs in CentAUR are protected by Intellectual Property Rights law, including copyright law. Copyright and IPR is retained by the creators or other copyright holders. Terms and conditions for use of this material are defined in the End User Agreement. 


\section{www.reading.ac.uk/centaur}

\section{CentAUR}

Central Archive at the University of Reading

Reading's research outputs online 
2 A novel solar-assisted ground-source heat pump (SAGSHP) with seasonal heat-storage and heat cascade utilization: field test and performance analysis

4 Tingting Sun ${ }^{\mathrm{a} *}$, Lingyan Yang ${ }^{\mathrm{b} *}, \mathrm{Lu} \mathrm{Jin}^{\mathrm{a}}$, Zhiwen Luo ${ }^{\mathrm{c}}$, Yan Zhang ${ }^{\mathrm{d}}$, Yanzhu Liu ${ }^{\mathrm{e}}$, Zhengru

$5 \quad$ Wang $^{\mathrm{d}}$

$6 \quad{ }^{\text {a }}$ School of Building Services Science and Engineering, Xi'an University of Architecture and

7 Technology, $710000 \mathrm{Xi}$ 'an, China

$8 \quad{ }^{b}$ China Academy of Building Research, 100013 Beijing, China

$9{ }^{\mathrm{c}}$ School of Construction Management and Engineering, University of Reading, RG6 6AY

10 Berkshire, United Kingdom

$11{ }^{\mathrm{d}}$ Haomaichangan Green Energy Limited (Shandong), 261000 Weifang, China

12 e Jian Engineering Project Management Limited (Shandong), 255000 Zibo, China

\section{*Corresponding author:}

17 Dr. Tingting Sun, School of the Building Services Science and Engineering, Xi'an University

18 of Architecture and Technology, China

19 Email: $\underline{\text { suntt@ } \mathrm{xauat} . e d u . c n}$

20 Dr. Lingyan Yang, China Academy of Building Research, China

21 Email: yly8111@163.com 
BHEs borehole heat exchangers

CP

GHS

HP

SCs

SAGSHPs

CCOP

SCOP

$F_{\text {mec }}$

$F_{m h p}$

$F_{m s c}$

$Q_{h p}$

$Q_{\mathrm{mr}}$

$Q_{m s c}$

$Q_{m u}$

$Q_{\text {тиес }}$

$Q_{m u h p}$

$Q_{\text {musc }}$

$R_{e c / r}$

$R_{e t / r}$

$R_{m r / v}$

$t_{a 1}$

$t_{b 2}$

$t_{s c 1}$

$t_{w l}$ circulation pump

ground heat storage

heat pump

solar collectors

solar-assisted ground-source heat pumps

coefficient of performance for compressor

coefficient of performance for the system

fraction of monthly heat contributed by heat extraction from core GHS

fraction of monthly heat contributed by the HP

fraction of monthly heat contributed by SCs

heat produced by the HP

monthly heat injected into the core region of the GHS

monthly valid heat gain of solar collectors

monthly heat supplied to the user side

monthly heat contributed by heat extraction from the core GHS

monthly heat contributed by the HP

monthly heat consumption of user side contributed by SCs

ratio of heat extracted from core GHS to the heat recharged into it

ratio of total heat-extraction from the ground to heat injected into it

month-averaged ratio of the heat injected into the ground to the valid heat gain of SCs

water temperature at the top of water tank A

water temperature at the bottom of water tank B

water temperature at the upper header of the SCs mounted on the Dwelling 3 roof

temperature measured at the borehole wall of $\mathrm{W} 1$ 


\section{Abstract}

25 To maintain the energy quality with high temperature and reduce the energy loss of seasonal heat-storage in solar-assisted ground-source heat pumps (SAGSHPs), a novel SAGSHP system with the heat-cascading of borehole heat-exchangers was designed and its field-test was conducted in this paper. The borehole heat-exchangers were divided into two regions: the core region and the peripheral region. The core region can maintain a high temperature (e.g. $\left.45^{\circ} \mathrm{C}\right)$, which is much higher than in previous studies, and the heat from this region can be used directly, without the operation of a heat pump. The field-test was conducted in a community in the province Shandong, China. The results indicate that a sufficient soil-temperature gradient (the temperature is high in the core but low at the periphery) can be created and maintained. The monthly averaged borehole-wall-temperature difference between the borehole heatexchangers (BHEs) at the core and the periphery can be as high as $30.1{ }^{\circ} \mathrm{C}$. This means that both cascaded heat-storage and heat-utilization can be realized. In addition, an average performance of $C C O P=5.15$ and $S C O P=4.66$ can be achieved. Compared with previous studies, despite the lower $C C O P$, a higher $S C O P$ can be attained, thanks to heat cascade storage and utilization. The novel approach described in this paper represents a viable alternative for space heating in North China.

Keywords: Solar-assisted ground-source heat pump; Seasonal heat-storage; Heat cascade utilization; Hybrid thermal system; Field testing; 


\section{Introduction}

During the past decades, ground-source heat pumps, a well-known type of renewable energy technology, have grown in popularity (Yuan et al., 2012; Luo et al., 2016). Because the temperature of the ground-soil changes less than the air temperature, and the evaporation temperature is higher for heating applications, and the condensation temperature is lower for cooling, ground source heat-pumps can reach higher energy-efficiencies than conventional airsource heat pumps (Sarbu et al., 2014). However, in heating-dominant buildings, the thermal imbalance of the soil can reduce the heating performance in the long-term (You et al., 2018; Fine et al., 2018; Li et at., 2018). To solve this problem, solar-assisted ground-source heat pump (SAGSHP) systems, where solar collectors are combined with a ground-source heatpump, are used in heating-dominant buildings (Olsson, 1984; Andrew et al., 2003). A SAGSHP system attempts to compensate the thermal imbalance of the ground soil and achieve a higher performance coefficient for the system (SCOP) in the long run (Xi et al., 2011; Yang et al., 2006). Furthermore, when seasonal heat-storage is added, solar collectors can be used throughout the whole year by injecting the heat into the ground soil using borehole heat exchangers (BHEs) even during non-heating seasons (Bauer et al., 2010). However, a significant disadvantage of conventional SAGSHPs which use seasonal heat-storage, is that the heat produced by solar collectors at a higher temperature (e.g. $50{ }^{\circ} \mathrm{C}$ or higher) is converted into the heat stored in the ground heat storage (GHS), which has a much lower temperature, e.g. $18{ }^{\circ} \mathrm{C}$ or lower (Liu et al., 2016). Thus, thermal energy quality is wasted.

Previously investigated SAGSHP systems normally use one of three strategies:

In the first strategy, the ground soil is used as heat source for the heat pump but not for solar heat storage. The heat produced by solar collectors can be used for space heating directly or as low temperature heat source for the heat pump together with the heat from BHEs. However, the heat is not injected into the ground even if heating demand is satisfied. This means, some 
heat is wasted, especially during non-heating seasons. Razavi et al. (2018) simulated a SAGSHP system that uses this strategy with TRNSYS. The group showed that power consumption could be reduced by $8.7 \%$ compared to a standalone ground-source heat pump. Bi et al. (2004) conducted an experiment on a SAGSHP system using this strategy, and a SCOP of 2.78 was reported.

In the second strategy, ground soil is not only used as heat source for the heat pump but also for short-term heat storage. This means the solar collectors can be used during the heating season. However, they are still idle during the non-heating seasons. Solar collectors and BHEs can work alternatingly, simultaneously, or independently. In the alternating operating mode, solar collectors operate during daytime, and the produced heat is injected into the ground soil, and the ground-source heat-pump operates in the evening to extract heat from the ground (Yang et al., 2015). According to the experimental study by Verma et al. (2017), the SCOP increased by $23 \%$ in this mode compared with a standalone ground-source heat-pump. In the simultaneous operating mode, solar collectors and BHEs can be connected in series or parallel with each other. Dai et al. (2015) reported that the SCOP reached 3.05 for series connection and 2.83 for parallel connection in their experimental study. Si et al. (2014) conducted a TRNSYS simulation in simultaneous mode and found that the soil temperature decreased by $0.8{ }^{\circ} \mathrm{C}$ after 10 years of operation, compared to $3.1{ }^{\circ} \mathrm{C}$ for a standalone ground-source heatpump. The independent working mode uses double U-tube BHEs (Cimmino and Eslami-Nejad, 2017; Shah et al., 2018). BHEs act as heat exchangers between the solar-collector loop and the ground-source heat-pump loop as well as a short-term heat storage. Weeratunge et al. (2018) optimized the system using CPLEX and reported a SCOP of 3.31 for the independent connection.

In the third strategy, ground soil is used as heat source for both the heat pump and seasonal heat-storage. A special characteristic of this operating strategy is that the solar collectors 
continue to operate during the non-heating seasons, and the heat is injected into the ground to increase the soil temperature (Stojanović and Akander, 2010). In other words, the solar collectors contribute to the thermal balance not only because less heat is extracted from the ground but also because more heat is injected into it throughout the year. Chen and Yang. (2012) conducted a TRNSYS simulation using this strategy and found that the SCOP could be improved by as much as $26.3 \%$ compared to a standalone ground-source heat-pump. In addition, the average ground-soil temperature increased by $0.21{ }^{\circ} \mathrm{C}$ each year instead of the expected decrease, according the experimental study by Zhu et al. (2015).

The SAGSHP with the seasonal heat storage is commonly considered a reasonable and efficient system. However, previous studies did not consider that the high-temperature heat produced by solar collectors was stored and used at a much lower temperature, which wastes thermal energy. In most studies, the heat that was produced by solar collectors was injected evenly into the GHS, and the soil temperature was generally quite low, e.g. $18^{\circ} \mathrm{C}$ or lower (Liu et al., 2016). Therefore, the heat medium, which is used to extract heat from the GHS, must be delivered to the evaporator of the heat pump to increase the temperature. This, however, means, the system performance remains low. Previous studies show that the soil temperature cannot reach more than $12{ }^{\circ} \mathrm{C}$ if only one or two BHEs are used in a SAGSHP system (Kjellsson et al., 2010; Reda, 2015; Georgiev et al., 2018; Trillat-Berdal et al., 2006; Niemann and Schmitz, 2019). Even if more BHEs were used, the soil temperature could barely exceed $20^{\circ} \mathrm{C}$ when the BHEs were connected in parallel (Emmi et al., 2015; Wang et al., 2010; Rad et al., 2013). Hesaraki et al. (2015) recommended a system, where many groups of BHEs were connected in series and the heat produced by solar collectors was injected into the GHS from the core to the periphery. However, the heat that was extracted from the GHS was generally used as a heat source for the heat pump, and heat cascade utilization was not discussed. Another similar configuration of a GHS was used in Okotoks, Canada (Pinel et al., 2011; Xu et al., 2014; 
Kandiah and Lightstone, 2016). The system had no heat pump, which means the heat could not be fully used when the soil temperature fell to below a certain level. Wang et al. (2012) performed a TRNSYS simulation, connecting 8/9 BHEs in series. The results showed that the peak soil temperature can reach $29^{\circ} \mathrm{C}, 25$ years later. However, the position-relation between BHEs and heat cascade utilization was not discussed. Furthermore, the extracted heat was also used only as a low-temperature heat-source for the heat pump.

To maintain the energy quality with higher temperature, heat-cascading is considered in this study of a promising novel SAGSHP system. The BHEs were divided into two regions: the core region and the peripheral region. Solar heat is injected into the core region, and a soil temperature gradient, which is higher in the core and lower at the periphery, is created (see details in Section 2.2). This is very different from the conventional uniform temperature-profile.

The biggest benefit is that heat cascade storage and utilization can be implemented. More specifically, the heat, which was extracted from the peripheral region at a lower temperature (e.g. $20^{\circ} \mathrm{C}$ ), was used as a low-temperature heat source for the heat pump. In addition, the heat, which was extracted from the core region at a higher temperature (e.g. $45^{\circ} \mathrm{C}$ ), was used for space heating, directly. The system construction and operating principle are described in this paper in detail, and a real-world project of this novel hybrid system for space heating is tested.

Finally, the system performance is evaluated in the subsequent sections.

\section{Description of the project background and the hybrid system}

\subsection{Real-world project background}

140 The targeted community, Datangfuyuan, is located in the City Gaomi (long. $119^{\circ} 26^{\prime} \mathrm{E}$ $120^{\circ} 01^{\prime} \mathrm{E}$, lat. $36^{\circ} 09^{\prime} \mathrm{N} \sim 36^{\circ} 41^{\prime} \mathrm{N}$, alt. $+7.5 \sim+109.4 \mathrm{~m}$, Fig. 1) in the province Shandong, China.

A detailed description of the local climate is shown in Tab. 1 (Xu et al, 2012a). The community consists of 9 dwellings - each has 6 floors. The total floor area is $22342 \mathrm{~m}^{2}$ with a total designed 


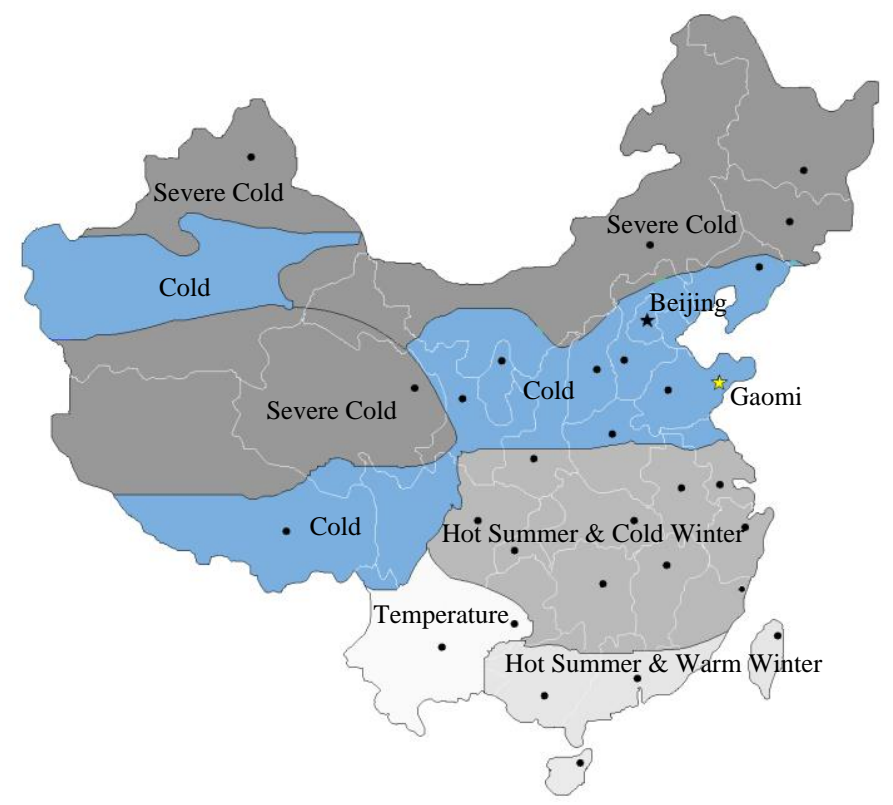

Fig. 1. Geographic location of Gaomi City, which is located in a cold climate zone in China

Table 1 Detailed description of the climatic conditions

\begin{tabular}{ll}
\hline \multicolumn{1}{c}{ Item } & \multicolumn{1}{c}{ Value/Description } \\
\hline Weather station (nearest to Gaomi) & Weifang (long. $119^{\circ} 111^{\prime} \mathrm{E}$, lat. $36^{\circ} 45^{\prime}$, \\
& alt. $+22.2 \mathrm{~m})$ \\
Outdoor heating design temperature in winter & $-7.0^{\circ} \mathrm{C}$ \\
Average temperature during the heating season & $-0.3{ }^{\circ} \mathrm{C}$ \\
Original soil-temperature (deep) & $14.8^{\circ} \mathrm{C}$ \\
Total horizontal solar radiation & $4613.6 \mathrm{MJ} /\left(\mathrm{m}^{2} \cdot \mathrm{y}\right)$ \\
Sunshine percentage in winter & $58 \%$ \\
Heating degree days at $18^{\circ} \mathrm{C}$ indoor & $2799{ }^{\circ} \mathrm{C} \cdot \mathrm{d}$ \\
\hline
\end{tabular}
conditioning of civil buildings. It is used to decide the scale of pace heating system

\subsection{System description}

153 The hybrid system (Fig. 2) consists of the following key-components - heat-pump unit, solar collectors, BHEs, water tanks, circulation pumps, heat exchanger, and a low-temperature hotwater radiant floor-heating system. One heat-pump set, with a nominal heating capacity of $352.3 \mathrm{~kW}$ and a heating rated power input of $75.7 \mathrm{~kW}$, was employed. Evacuated-tube solar- 
collectors were used because of their excellent anti-freeze capabilities. 212 sets of solar collectors (diameter: $58 \mathrm{~mm}$, length: $1800 \mathrm{~mm}$, tubes: 50), filled with ethylene glycol, were mounted on the roofs of the dwellings. They faced south and were tilted at an angle of $36^{\circ}$. Two water tanks, with the same volume $\left(125 \mathrm{~m}^{3}\right)$, were used as a thermal buffer as well as short-term heat-storage. By connecting the bottom of the water tank A with the top of water tank B, a thermal stratification was created.

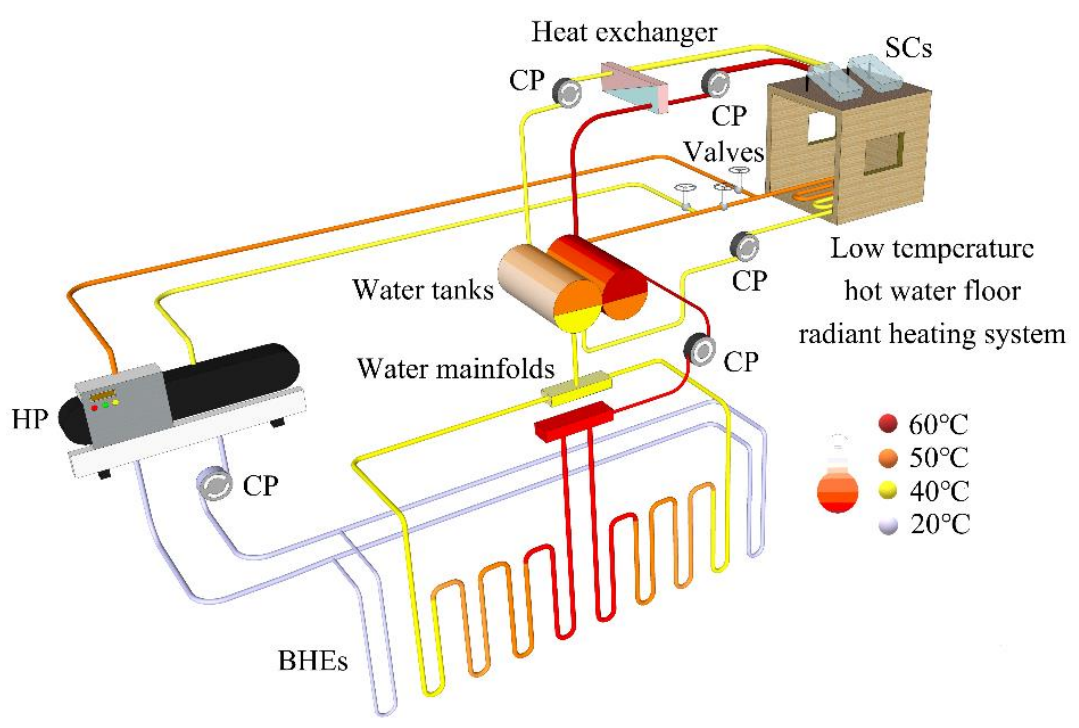

Fig. 2. Schematic of the novel hybrid-system (HP: heat pump, CP: circulation pump, SCs: solar collectors, BHEs: borehole heat-exchangers)

In total, 150 single U-pipe BHEs were installed. The borehole depth was $75 \mathrm{~m}$, and the diameter is $150 \mathrm{~mm}$. Thus, the total pipe-length in the BHEs was $22,500 \mathrm{~m}$. The borehole pitches between the BHEs are shown in Fig. 3. These BHEs were divided into 2 groups, the core region and the peripheral region. Solar heat was injected into the BHEs of the core region but not into the peripheral region. In the core region, 76 BHEs were organized into 19 loops. There were 4 BHEs in each loop, which were connected in series. The heat medium flew through the BHE near the core first, then, sequentially, to the other three BHEs that were located further from the core, during the injection of heat into the ground - see Fig. 3. When heat was extracted from the ground, the heat-medium flow-direction could be reversed using the on/off remote- 
controlled valves $\mathrm{V}_{\mathrm{a} 1}-\mathrm{V}_{\mathrm{a} 6}$ - see Fig. 4. This design creates a temperature gradient, with a higher temperature in the core and a lower one at the periphery. This also enables heat cascade storage and utilization. During the heating season, the heat, which was extracted from BHEs in the core region, could be used directly for space heating without the heat pump if the temperature was high enough. Even when the temperature was not high enough for direct heating, the BHEs in the core region were connected to the condenser of the heat pump via water tanks (instead of the evaporator) - see Fig. 4. This makes better use of the heat at higher temperature, e.g. at $45^{\circ} \mathrm{C}$, compared to the heat from peripheral region that could be at only $20{ }^{\circ} \mathrm{C}$. There were 74 BHEs in the peripheral region. These were connected in parallel with each other and with the evaporator of the heat pump, which was used as a low-temperature heat-source. Furthermore, the BHEs in the core region were not used as low-temperature heat-sources for the heat pump. This way it was possible to maintain a higher temperature in the core and contribute to a temperature gradient that points from the periphery to the core.

188

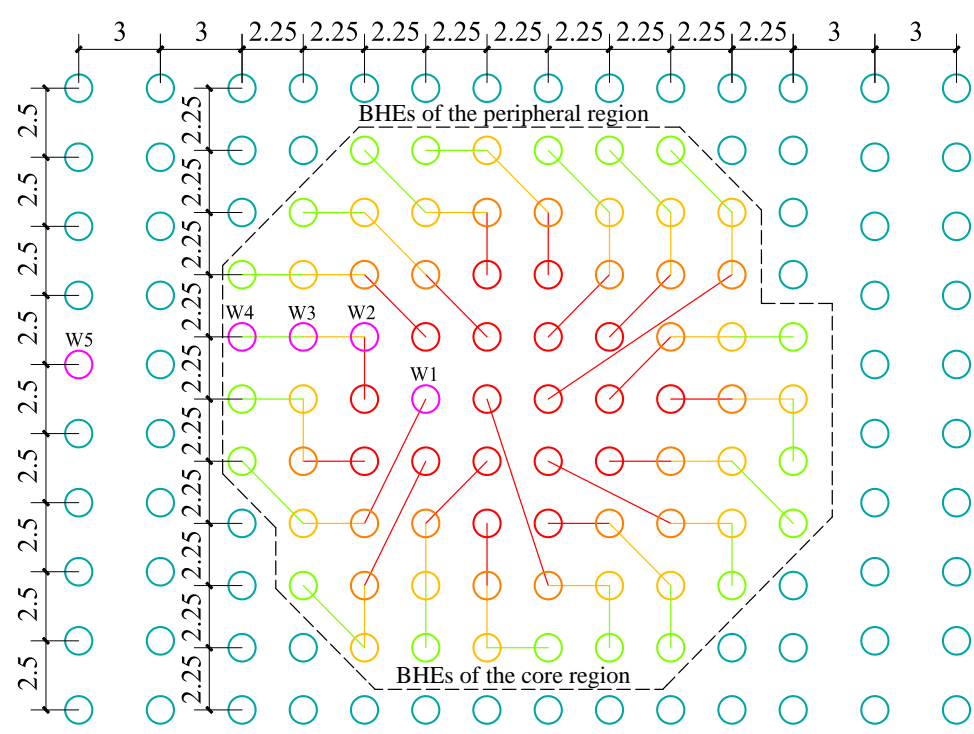

Fig. 3. Arrangement and division of BHEs for GHS. The transition of colour from red to blue represents a temperature gradient from high to low. Pink wells (W1 W5) mark the measurement points for the borehole-wall temperature. 


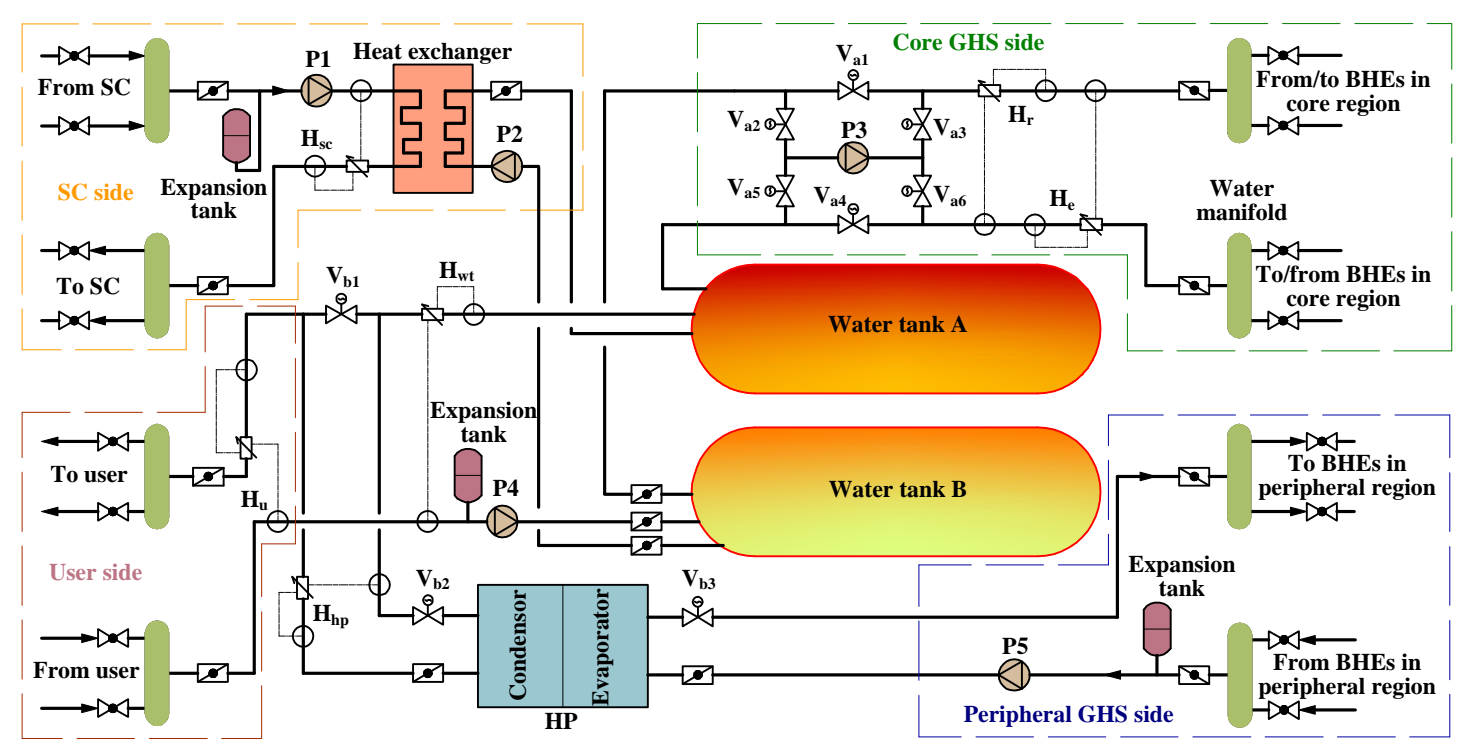

\section{(1) Pum}

LEGEND

Fig. 4. Schematic of the hybrid system

(SC: solar collector, GHS: ground heat storage)

On the top of the GHS sits an insulation board, which is made of extruded poly styrene (XPS) and a moisture barrier made of high-density polyethylene (HDPE). Prior to the project design, thermal-response tests were performed. The tests were carried out from 31 Jul to 2 Aug 2014, with inlet and outlet temperatures of $27.4{ }^{\circ} \mathrm{C}$ and $24{ }^{\circ} \mathrm{C}$, respectively. The results were: the initial temperature in deep ground, without disturbance, was $t_{i}=14.8^{\circ} \mathrm{C}$, thermal conductivity was $\lambda=2.176 \mathrm{~W} / \mathrm{m} \cdot \mathrm{K}$, the specific heat capacity was $C_{p}=1.39 \mathrm{MJ} / \mathrm{m}^{3}$, and heat flux was $q=40.7$ $\mathrm{W} / \mathrm{m}$.

\subsection{Operating modes}

The system operates in different modes, depending on climate and heating demand (see Tab. 2). These can be described as follows:

Non-heating mode: During non-heating season, the solar-collector side (see Fig. 4) operates, when solar radiation is high. The antifreeze-liquid in the solar collectors captures heat and delivers it to water tanks via a heat exchanger and the circulation pumps, P1 and P2. Heat, which was conserved in the water tanks was injected into the core region of the GHS, driven 
by P3. The heat pump and the user side were switched-off in this mode because there is no heating demand.

Heating mode: During heating season, heat produced by solar collectors could be used directly for space heating. Heat, which was extracted from the BHEs in the core region, were a second support option if the solar collectors alone were not sufficient to meet the heating demand. The heat pump was turned on when both, solar collectors and the heat extracted from the core region, were not sufficient.

\subsection{Control strategy}

The control strategy is summarized in Tab. 2 .

Solar-collector side: The on/off control of the solar-collector side was based on the monitors for the water temperature at the top of the water tank A $\left(t_{a l}\right)$ and the upper header of the solar collectors mounted on the Dwelling 3 roof $\left(t_{s c l}\right)$. As shown in Tab. 2, circulation pumps (P1 and P2) begin to operate when $t_{s c l}>90{ }^{\circ} \mathrm{C}$. The operation continues until $t_{s c l}<t_{a l}+10{ }^{\circ} \mathrm{C}$. The control parameters were identical for the heating and non-heating seasons.

User side: The user side operates intermittently during heating-season and was controlled by skilled engineers. The first two heating seasons for this project were from 2 Nov 2015 to 22 Mar 2016, and from 11 Nov 2016 to 18 Mar 2017.

Core GHS side: There are two operating conditions for the core GHS side: injecting heat into the GHS during the non-heating season and extracting heat from it during heating season (see Tab. 2). Heat injection starts for $t_{a l}>t_{w l}+15^{\circ} \mathrm{C}$, where $t_{w l}$ is the temperature measured at the borehole wall of $\mathrm{W} 1$ - see Fig. 3. Heat injection lasts until $t_{a 1}<t_{w l}+10{ }^{\circ} \mathrm{C}$, while heat extraction only takes place during the heating season. It starts if the two conditions are satisfied at the same time: $t_{w 1}>t_{b 2}+10{ }^{\circ} \mathrm{C}$ and $t_{a l}<50{ }^{\circ} \mathrm{C}$, where $t_{b 2}$ is the water temperature at the bottom of water tank B. When the core GHS side operates in injection mode, the valves $\mathrm{V}_{\mathrm{a} 2}, \mathrm{~V}_{\mathrm{a} 3}$, and $\mathrm{V}_{\mathrm{a} 4}$ are closed, while the valves $\mathrm{V}_{\mathrm{a} 1}, \mathrm{~V}_{\mathrm{a} 5}$, and $\mathrm{V}_{\mathrm{a} 6}$ are open - see Fig. 4. Water is pumped from the 
top of the water tank A to the BHEs in the core GHS, which is shown in red in Fig 3, via the water manifold A. After the heat exchange, water was collected by the water manifold B and returned to the bottom of water tank B. On the other hand, when operating in extraction mode,

237 the valves $\mathrm{V}_{\mathrm{a} 2}, \mathrm{~V}_{\mathrm{a} 3}$, and $\mathrm{V}_{\mathrm{a} 4}$ were open, while the valves $\mathrm{V}_{\mathrm{a} 1}, \mathrm{~V}_{\mathrm{a} 5}$, and $\mathrm{V}_{\mathrm{a} 6}$ were closed. Then, 238 the direction of the water flow reversed.

Heat pump and peripheral GHS side: The heat-pump operates only when the two conditions were satisfied simultaneously, i.e., the user side was operating and $t_{a l}<50{ }^{\circ} \mathrm{C}$. If the heat pump works, valve $\mathrm{V}_{\mathrm{b} 1}$ was closed, and valves $\mathrm{V}_{\mathrm{b} 2}$ and $\mathrm{V}_{\mathrm{b} 3}$ were opened. Otherwise the opposite occurred.

Table 2 Operating modes and control strategies

\begin{tabular}{|c|c|c|c|c|}
\hline Season & $\begin{array}{l}\text { User } \\
\text { side }\end{array}$ & $\begin{array}{c}\text { Solar } \\
\text { collector } \\
\text { side }\end{array}$ & $\begin{array}{c}\text { Core } \\
\text { GHS } \\
\text { side } \\
\end{array}$ & $\begin{array}{c}\text { Heat pump } \\
\& \text { peripheral GHS side }\end{array}$ \\
\hline $\begin{array}{l}\text { Non- } \\
\text { heating }\end{array}$ & $\mathrm{OFF}$ & $\begin{array}{l}\text { Solar heat is } \\
\text { used for heat } \\
\text { injection to the } \\
\text { ground. }\end{array}$ & $\begin{array}{l}\text { Heat is injected into } \\
\text { the ground. Open } \\
\text { valves: } \mathrm{V}_{\mathrm{a} 1}, \mathrm{~V}_{\mathrm{a} 5}, \mathrm{~V}_{\mathrm{a} 6} ; \\
\text { Close valves: } \mathrm{V}_{\mathrm{a} 2}, \\
\mathrm{~V}_{\mathrm{a} 3}, \mathrm{~V}_{\mathrm{a} 4} \text {. }\end{array}$ & OFF \\
\hline $\begin{array}{l}\text { Control } \\
\text { strategy }\end{array}$ & & $\begin{array}{l}\text { If } t_{s c 1}>90{ }^{\circ} \mathrm{C} \\
\text { turn on pumps } \\
\mathrm{P} 1, \mathrm{P} 2 \text {. } \\
\text { If } t_{s c 1}<t_{a 1}+10 \\
\text { turn off pumps } \\
\mathrm{P} 1, \mathrm{P} 2 \text {. }\end{array}$ & $\begin{array}{l}\text { If } t_{a 1}>t_{w 1}+15^{\circ} \mathrm{C} \text {, } \\
\text { turn on pump } \mathrm{P} 3 \text {. } \\
\text { If } t_{a 1}<t_{w 1}+10^{\circ} \mathrm{C} \text {, } \\
\text { turn off pump P3. }\end{array}$ & \\
\hline Heating & $\begin{array}{l}\text { Operates } \\
\text { intermittently }\end{array}$ & $\begin{array}{l}\text { Valid heat gain } \\
\text { is used for space } \\
\text { heating. }\end{array}$ & $\begin{array}{l}\text { Heat is extracted } \\
\text { from the ground. } \\
\text { Close valves: } \mathrm{V}_{\mathrm{a} 1} \text {, } \\
\mathrm{V}_{\mathrm{a} 5}, \mathrm{~V}_{\mathrm{a} 6} \text {; } \\
\text { Open valves: } \mathrm{V}_{\mathrm{a} 2} \text {, } \\
\mathrm{V}_{\mathrm{a} 3}, \mathrm{~V}_{\mathrm{a} 4} \text {. }\end{array}$ & $\begin{array}{l}\text { Only operates when the heat } \\
\text { from SCs and core GHS } \\
\text { cannot meet the heating } \\
\text { demand. }\end{array}$ \\
\hline $\begin{array}{l}\text { Control } \\
\text { strategy }\end{array}$ & $\begin{array}{l}\text { Controlled by } \\
\text { skilled } \\
\text { engineers. }\end{array}$ & $\begin{array}{l}\text { The same as } \\
\text { non-heating } \\
\text { season. }\end{array}$ & $\begin{array}{l}\text { If } t_{w 1}>t_{b 2}+10^{\circ} \mathrm{C} \text { and } \\
t_{a 1}<50{ }^{\circ} \mathrm{C} \text {, turn on } \\
\text { pump P3. Otherwise, } \\
\text { turn off pump P3. }\end{array}$ & $\begin{array}{l}\text { If the user side operates and } \\
t_{a 1}<50{ }^{\circ} \mathrm{C} \text {, turn on the heat } \\
\text { pump; turn on pump } \mathrm{P} 5 \text {; } \\
\text { open valves } \mathrm{V}_{\mathrm{b} 2}, \mathrm{~V}_{\mathrm{b} 3} \text {; close } \\
\text { valve } \mathrm{V}_{\mathrm{b} 1} \text {. Otherwise the } \\
\text { opposite is true. }\end{array}$ \\
\hline
\end{tabular}




\subsection{Data collection}

247

The data-collection system includes the temperature-measurement system, heat-measuring system, and electricity-measurement system. The indoor temperature of four sample flats, outdoor temperature, soil temperature at the borehole wall, water temperature at the top of water tank $\mathrm{A}$ and the bottom of water tank $\mathrm{B}$, and the water temperature at the top header of the solar collectors were measured. To measure the borehole wall temperatures, sensors were buried in suitable boreholes (W1 W5), which are highlighted in pink in Fig. 3. As reported in the literature (Niemann and Schmitz, 2019; Xi et al., 2017), the borehole-wall temperaturechange in the vertical direction was small and could be ignored. Thus, only one measurement point was set for each borehole, at a depth of $30 \mathrm{~m}$. In addition, the heat meter $\mathrm{H}_{\mathrm{sc}}$ was used to measure the heat flux produced by the solar collectors. The heat meters $\mathrm{H}_{\mathrm{r}}$ and $\mathrm{H}_{\mathrm{e}}$, were used to measure the heat injected into and extracted from the BHEs in the core region. The heat meters $\mathrm{H}_{\mathrm{wt}}$ and $\mathrm{H}_{\mathrm{hp}}$, were used to measure the heat supplied by the water tanks and the heat produced by the heat-pump condenser. And the heat meter $\mathrm{H}_{\mathrm{u}}$ was used to measure the heat supplied to the user side - see Fig. 4. Two electricity meters were used to measure the electric input. One was used to measure electric input for the whole system, including all pumps and the heat pump. The other one was used to measure the electric input for the heat pump separately. Detailed information of the used devices is provided in Tab. 3. All data were logged within an interval of $30 \mathrm{~min}$.

\subsection{Uncertainty analysis}

The uncertainty analysis in the field test includes the error estimation for both measured and calculated parameters. The relative errors of the measured and calculated parameters can be obtained using the following equations (Dai et al., 2015):

$\Delta X_{i} / X_{i}=\lambda_{x} \cdot L_{x} / X_{i}$ 
$\Delta Y_{i} / Y_{i}=\sqrt{\sum_{1}^{n}\left(\frac{\partial Y_{i}}{\partial X_{i}} \lambda_{x} \cdot L_{x}\right)^{2}} / Y_{i}$

271 where $L_{x}$ is the upper limit of the measuring range, $\lambda_{x}$ is the accuracy according to the manufacturer, $X_{i}$ is the value of a measured parameter, $Y_{i}$ is a function of a series of measured independent variables. The relative errors of the main parameters in the field test are shown in Tab. 4.

Table 3 Specifications of the used measurement devices

\begin{tabular}{cccc}
\hline Device & Type & $\begin{array}{c}\text { Measurement } \\
\text { range }\end{array}$ & Accuracy \\
\hline Temperature sensor & WZP-230PT100 & $0-100{ }^{\circ} \mathrm{C}$ & $\pm(0.15+0.002|\mathrm{t}|){ }^{\circ} \mathrm{C}$ \\
Heat meter & CRL-G(DN80,65) & $/$ & $3+4 \Delta \mathrm{t}_{\min } / \Delta \mathrm{t}+0.02 \mathrm{q}_{\mathrm{p}} / \mathrm{q}$ \\
Electricity meter & $400 / 5$ & $/$ & $\pm 1 \%$ \\
\hline
\end{tabular}

Table 4 Uncertainty of the main parameters

\begin{tabular}{lllll}
\hline Parameters & Unit & $\begin{array}{l}\text { Relative } \\
\text { uncertainty } \\
(\%)\end{array}$ & Parameters & $\begin{array}{l}\text { Relative } \\
\text { uncertainty } \\
(\%)\end{array}$ \\
\hline Outdoor temperature & ${ }^{\circ} \mathrm{C}$ & 0.85 & $F_{m e c}$ & 6.55 \\
Indoor temperature & ${ }^{\circ} \mathrm{C}$ & 0.80 & $F_{m h p}$ & 7.15 \\
borehole wall temperature & ${ }^{\circ} \mathrm{C}$ & 0.47 & $F_{m s c}$ & 8.12 \\
Heat at solar side & $\mathrm{kW} \cdot \mathrm{h}$ & 4.25 & $R_{e c / r}$ & 6.22 \\
Heat at core GHS side (injected) & $\mathrm{kW} \cdot \mathrm{h}$ & 3.64 & $R_{m r / v}$ & 6.21 \\
Heat at core GHS side (extracted) & $\mathrm{kW} \cdot \mathrm{h}$ & 5.05 & $R_{e t / r}$ & 6.57 \\
Heat supplied to user side & $\mathrm{kW} \cdot \mathrm{h}$ & 5.42 & $C C O P$ & 5.78 \\
Heat produced by heat pump & $\mathrm{kW} \cdot \mathrm{h}$ & 5.42 & $S C O P$ & 4.61 \\
Heat from water tank to user side & $\mathrm{kW} \cdot \mathrm{h}$ & 5.42 & & \\
power consumption of heat pump & $\mathrm{kW} \cdot \mathrm{h}$ & 1 & & \\
\& circulation pumps & & & & \\
power consumption of heat pump & $\mathrm{kW} \cdot \mathrm{h}$ & 2 & & \\
\hline
\end{tabular}

\section{Test results and performance analysis}

4.1 Indoor- and outdoor- temperature during the heating season

281 The heating season started from 11 Nov 2016, but the indoor temperature records were from $10^{\text {th }}$ of Dec 2016. As shown in Fig. 5, most of the day-averaged indoor temperatures met the 

infrequent, and they may have been caused by opened windows for example since the occupants were not instructed to follow any special procedures. This means the space-heating requirements were adequately met using this hybrid system.

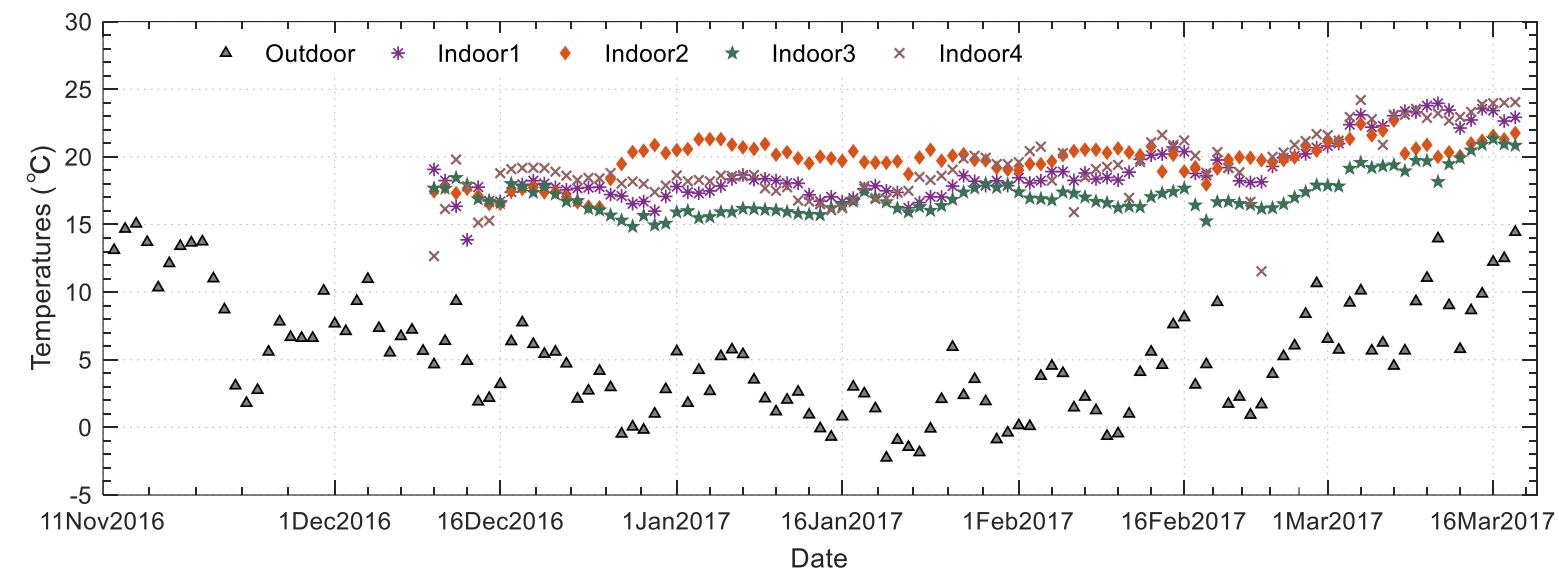

Fig. 5. Day-averaged indoor and outdoor temperature during the heating season

\subsection{Monthly supplied heat to the user during the heating season}

As illustrated in Fig. 6 (a), the monthly heat supplied to the user, $Q_{m u}$, during the first heating season (Nov $2015 \sim$ Mar 2016), varied parabolically. The peak value of $65.08 \mathrm{MW} \cdot \mathrm{h}$ occurred on Jan 2016 with the lowest value (29.97 MW·h) on Nov 2015. While the trend of $Q_{m u}$ during the second heating-season (Nov 2016 Mar 2017) was similar to the first one, the absolute values were much higher due to a higher occupancy rate. The highest $Q_{m и}$ occurred on Jan 2017 when 158.87 MW'h were reached, while the lowest value was recorded on Nov 2016 (53.68 MW $\cdot h)$. The total heat supplied to the user side for the two heating seasons were, respectively, 229.97 MW'h and 580.63 MW'h. According to Fig. 6, the monthly heat, which was supplied to the user by solar collectors $\left(Q_{\text {musc }}\right)$, showed little difference for the two heating seasons in the respective months. Yet, according to Fig. 7, their fractions $\left(F_{m s c}\right)$ for the first heating season were vastly higher than for the second. This is because the capacity of the solar collectors did not increase with increased heating demand, i.e., a lower $Q_{m u}$ caused a higher $F_{m s c}$. On the other hand, a higher heating demand means a larger contribution by the heat pump, independent of 
$Q_{m u h p}$ or $F_{m h p}$ - see Figs 6 and 7. Furthermore, the system was able to work with a higher SCOP

304 ( = the heat supplied to the user side by the hybrid system divided by the total electricity 305 consumed by the system including circulation pumps and heat pump) when the community had 306 a lower occupancy rate. The contribution of the heat extracted from the core GHS also 307 increased both in value $\left(Q_{\text {тиес }}\right)$ and fraction $\left(F_{m h p}\right)$ for the second heating season compared to 308 the first one. As much as $2.87 \mathrm{MW} \cdot \mathrm{h}$ and $0.36 \mathrm{MW} \cdot \mathrm{h}$ of heat were extracted from the core GHS on Nov and Dec during the first heating season. The values for the second heating season were 15.20 MW'h and 40.80 MW'h. In addition, 7.00 MW'h and 0.25 MW'h heat were extracted from the core GHS on Jan and Feb during the second heating season. This occurred because heat accumulation had not been so large for the first heating season. According to Fig. 7, due to the higher soil temperature at the beginning of the second heating season, the contribution 314 fractions for heat extraction from core GHS $\left(F_{m e c}\right)$ on Nov and Dec 2016 were much higher than for later months. Heat extraction from core GHS mainly occurred on Nov and Dec 2016, which accounted for $88.5 \%$ of the total of the whole heating season.

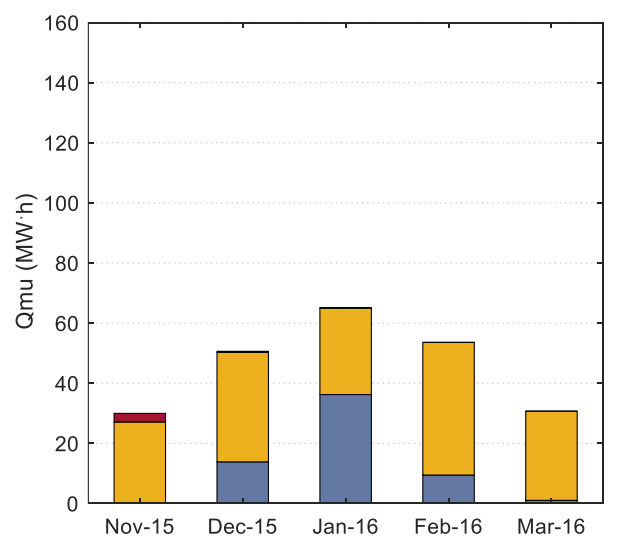

a

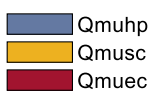

318

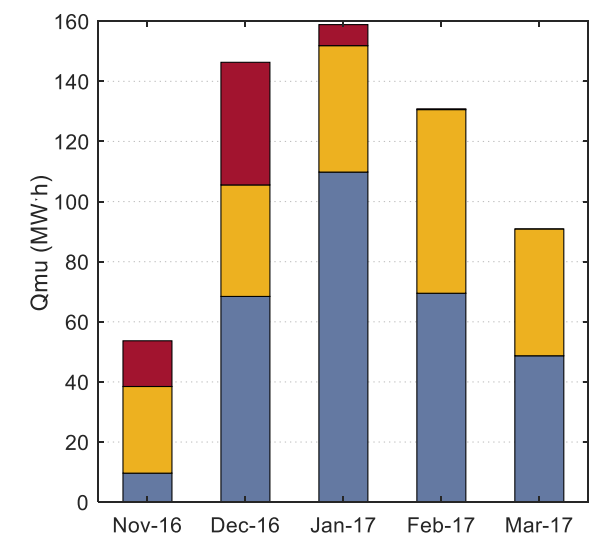

b

Fig. 6. Monthly heat-consumption on user side and its composition 


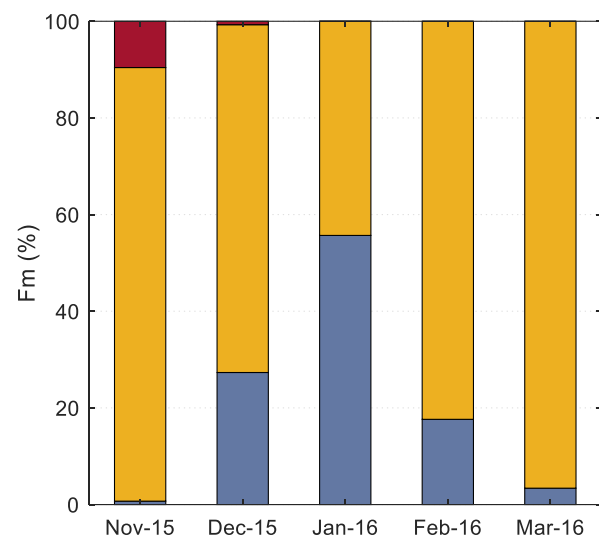

a
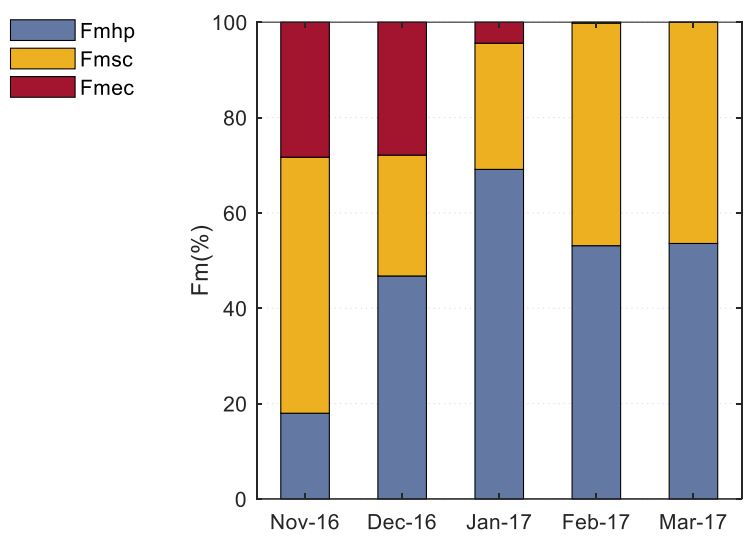

b

Fig. 7. Fractions of contributions for heat from the heat pump, solar collectors, and extracted

\section{from core GHS}

\subsection{CCOP during the heating season}

Average $C C O P$ (=the heat produced by heat pump divided by the electricity consumed by the heat-pump compressor) during different periods of the second heating season are depicted in Fig. 8. The highest average $C C O P$ of 6.05 occurred in the earliest period in the heating season. A downward trend can also be identified using this chart. The lowest value of 4.72 occurred in the last period of the heating season. This is because the soil temperature reached the peak value at the start of the heating season after as many as 8 months of heat injection. The soil temperature gradually decreased as heat was continually extracted from the ground and diffused to the surrounding soil. Interestingly, an increase of $C C O P$ was observed for the period from 16 Feb to 26 Feb - see Fig. 8. This is because the heat production by the heat pump $\left(Q_{h p}\right)$ during this period was at a low level. Because a lower $Q_{h p}$ caused less heat-exchange demand between the heat medium in the BHEs and the surrounding soil, a lower temperature difference was needed. Hence, the inlet water temperature for the heat-pump evaporator increases. Furthermore, thanks to reduced heat extraction from the BHEs, the soil temperature near the BHEs could recover faster. The temperature recovery also increases the temperature of the water supplied to the evaporator. For these two reasons, a higher $C C O P$ was achieved. A 

increased slightly.

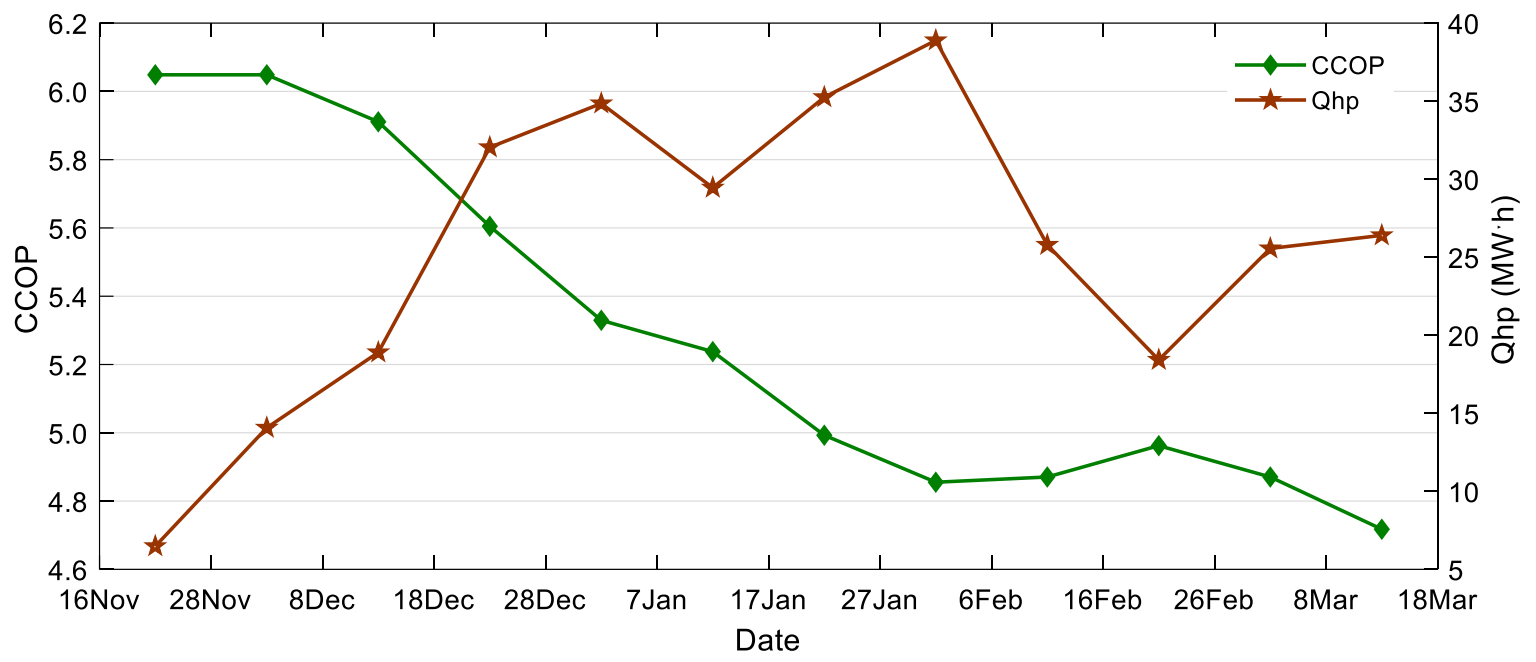

Fig. 8. The average values of $C C O P$ and $Q_{h p}$ during different periods

\subsection{Valid heat gain of solar collectors and its destination}

Fig. 9 (a) shows the monthly valid heat gain of solar collectors $\left(Q_{m s c}\right)$ during a calendar year in 2016. $Q_{m s c}$ on June was the highest for the whole year, with $99.17 \mathrm{MW} \cdot \mathrm{h}$. The values for May and July were second and third, with about $95 \mathrm{MW} \cdot \mathrm{h}$. Unfortunately, $Q_{m s c}$ was generally low in the months during heating season. January and December had the lowest $Q_{m s c}$ of the year, with $36.34 \mathrm{MW} \cdot \mathrm{h}$ and $37.14 \mathrm{MW} \cdot \mathrm{h}$, respectively. There are two reasons for this phenomenon.

The first one is that the outdoor temperature was low during these months, which reduced the efficiency of the solar collectors. The second reason is that, the subsolar point was far from the targeted city during heating season. As a result, less solar radiation reached the solar collectors. These two reasons are applicable to all cities in north China. Thus, the variations of the valid heat gain of solar collectors for different cities are similar. Considering this, a seasonal heatstorage is indispensable to make full use of solar collectors for the entire year. The monthly heat injected into the core GHS $\left(Q_{\mathrm{mr}}\right)$ is shown in yellow in Fig. 9 (a). The month-averaged ratio of the heat injected into the ground to the valid heat gain of solar collectors $\left(R_{m r / v}\right)$ is 
shown in purple. For most of the non-heating months, $R_{m r / v}$ exceeded $90 \%$. An exception was on October with $88 \%$. Heat was rarely injected into the ground during the heating season, so that it could be efficiently utilized for space heating directly.

As shown in Fig. 9 (b), the total valid heat gain of the solar collectors for the year was 838.99 MW.h. A fraction of $70 \%(528.63 \mathrm{MW} \cdot \mathrm{h})$ was injected into the core GHS, and a fraction of $25 \%(211.28 \mathrm{MW} \cdot \mathrm{h})$ was used directly for space heating. The remaining $5 \%(45.08 \mathrm{MW} \cdot \mathrm{h})$ were lost to ambient air.

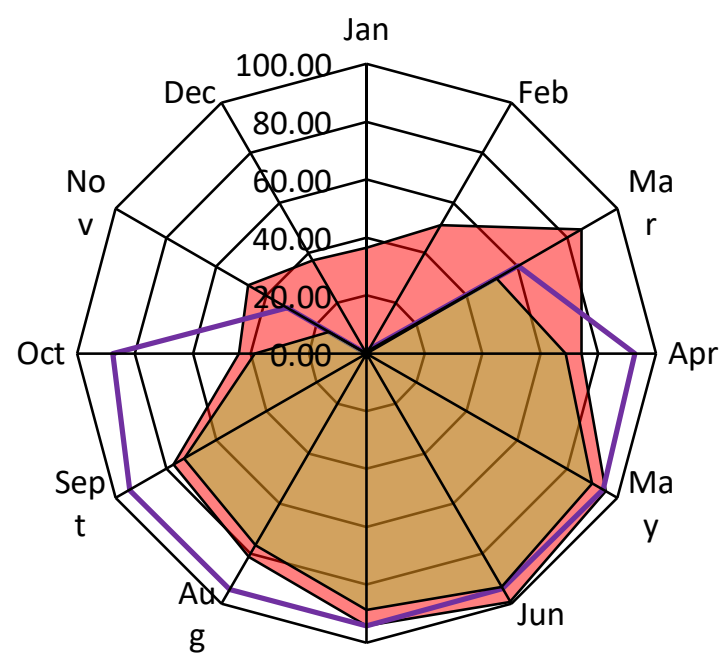

Jul $\square$ Qmsc (MW'h)

$\square \mathrm{Rmr} / \mathrm{v}(\%)$

$\square \mathrm{Qmr}(\mathrm{MW} \cdot \mathrm{h})$

a Monthly valid heat-gain of solar collectors and its injection in the ground

b Percentages of different destinations for valid heat gain of solar collectors Fig. 9. Valid heat gain of solar collectors and its destination

\subsection{Heat injected into (and extracted from) core GHS}

The ratio of heat extracted from core GHS to the heat injected into it $\left(R_{e c / r}\right)$ is a primary parameter to evaluate the performance of both heat cascade utilization and seasonal heat storage. A higher $R_{e c / r}$ means that the heat cascade utilization and seasonal heat storage are more efficient. The monthly heat injected and extracted during the period of July 2015 to May 
2017 is shown in Fig. 10. The period before Feb 2016 is defined as the first recharge/extraction cycle, while the period from Mar 2016 to Feb 2017 is defined as the second recharge/extraction cycle. During the first recharge/extraction cycle, little heat was extracted from core GHS, and $R_{e c / r}$ was very low, less than $1 \%$. The maximum monthly heat, which was extracted from core GHS was only 2.87 MW' $\mathrm{h}$. The reasons for this were given in Section 4.2. For the second recharge/extraction cycle, the monthly heat, which was extracted from core GHS, increased significantly (to 15.20 MW'h, 40.80 MW'h and 7.00 MW'h in Nov, Dec 2016, and Jan 2017). $R_{e c / r}$ increased to $10.86 \%$ as a result of substantial heat accumulation in the GHS. This is considered to be a sufficiently good number. As the heat accumulation in the core GHS continued, a higher $R_{e c / r}$ could be expected because an upward trend for the borehole wall temperature was observed in the core region, when the first and the second recharge/extraction cycle (see Section 4.6) were compared.

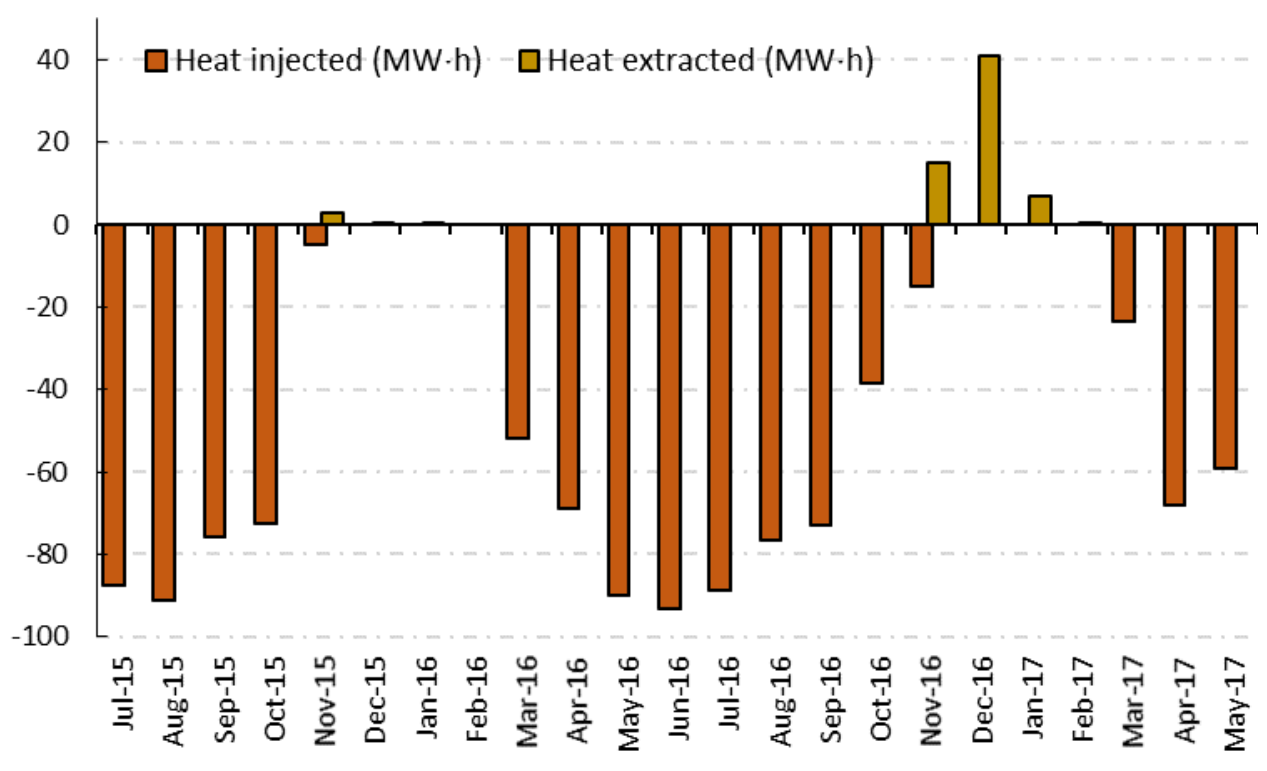

Fig. 10. Monthly heat extracted $(\mathrm{MW} \cdot \mathrm{h})$ from core GHS

\subsection{Variation of borehole wall temperatures}

The variation of the month-averaged borehole wall temperatures in the respective BHEs (Fig. 3) is shown in Fig. 11. A significant temperature-gradient, which was higher in the core and lower at the periphery, can be seen. The temperature difference between W1(at the core) and 
395

396

397

398

399

400

401

402

403

404

405

406

407

408

409

410

411

412

W5 (at the periphery) increased during the second recharge/extraction cycle compared with the first one, which increased from $19.4{ }^{\circ} \mathrm{C}$ in Jun 2015 to $30.1{ }^{\circ} \mathrm{C}$ in Nov 2017. These results are very promising for heat cascade storage and utilization. According to Fig. 11, the peak value of $\mathrm{W} 1$ reached $56.6{ }^{\circ} \mathrm{C}$ in Oct 2016. As measured, the outlet medium temperature of the extracted heat from the core GHS, can reach $43.4{ }^{\circ} \mathrm{C}$ at the start of the second heating season. This temperature was much higher than the one reported in other studies, for example, $15.2{ }^{\circ} \mathrm{C}$ in $\mathrm{Li}$ et al. (2018). It exceeded the maximum recommended inlet water temperature $\left(20^{\circ} \mathrm{C}\right)$ for the heat pump evaporator in heating mode according to the product specifications (Menergy, 2019). Thus, the water, which extracted heat from the core ground heat-storage, was pumped to the user directly or to the condenser of the heat pump. Heat could be utilized at higher temperature using this approach. On the other hand, the water that extracts heat from peripheral BHEs can reach the evaporator of the heat pump and be used as heat source. In other words, cascaded heat utilization was realized successfully.

In addition, as seen in Fig. 11, the highest month-averaged temperature of $\mathrm{W} 1 \sim \mathrm{W} 4$, for the core region, sharply increased compared to the first and the second recharge/extraction cycle. The average growth was $9.9{ }^{\circ} \mathrm{C}$, while the highest monthly-averaged temperature in $\mathrm{W} 5$ at the periphery increased by $5.9^{\circ} \mathrm{C}$. The temperature increase in the core region suggests a larger potential of energy usage at the higher temperature. 


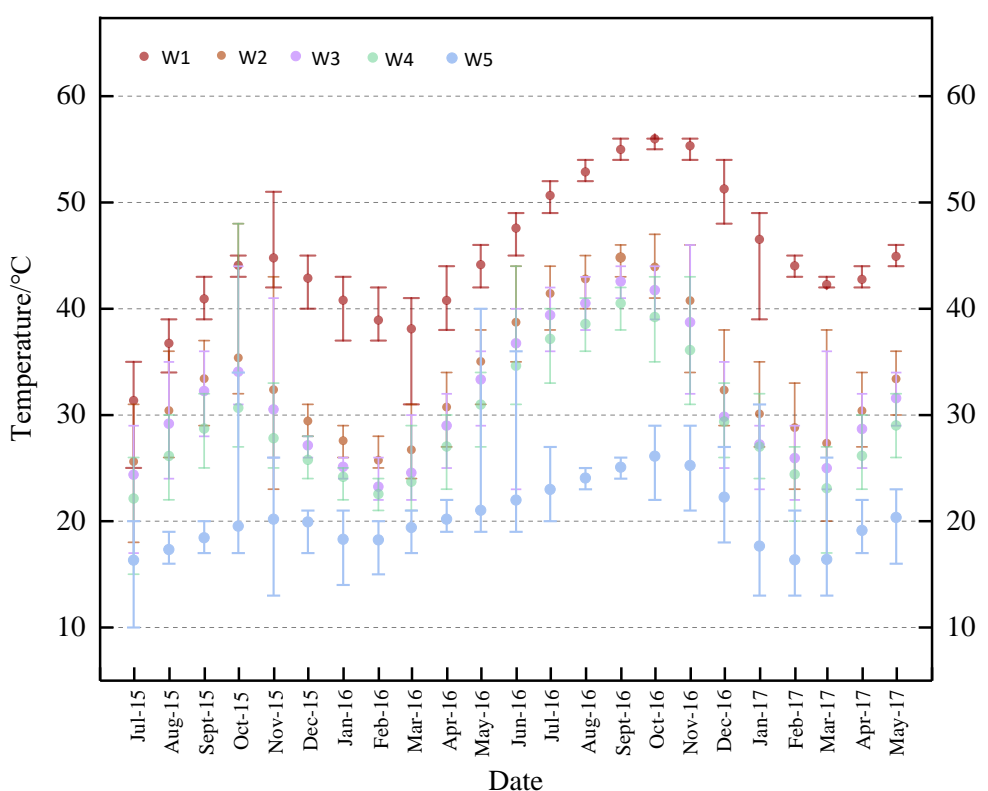

414 Fig. 11. Variation of the borehole-wall temperatures in the borehole heat exchangers W1 W5

\section{$415 \quad 4.7$ Energy balance of the hybrid system}

416 To learn more about the performance of the hybrid system, the energy-flow between the

417 different components in the second recharge/extraction cycle are shown in Fig. 12. The total 418 valid heat gain of the solar collectors was measured to be $838.99 \mathrm{MW} \cdot \mathrm{h}$, of which $582.63 \mathrm{MW} \cdot \mathrm{h}$ 419 was injected into the core GHS. Simultaneously, $63.25 \mathrm{MW} \cdot \mathrm{h}$ was extracted from core GHS, and 266.00 MW'h was supplied to the user side from the water tanks. All the above values were measured using heat meters. According to the energy-conservation principle, a total heatloss of 53.61 MW'h took place. For the heat pump, the heat meter measured a heat flow of 306.10 MW'h at the condenser side, and the power meter showed 59.39 $\mathrm{MW} \cdot \mathrm{h}$ of electric input, which means that the average $C C O P$ was $5.15(306.10 / 59.39=5.15)$. Furthermore, as much as 246.71 MW' $h$ of heat was extracted from the BHEs in the peripheral region. The ratio of total heat-extraction from the ground to heat injected into it, $R_{e t / r}$, was $53.2 \%$ $((63.25+246.71) / 582.63=53.2 \%)$. On the other hand, the ratio of heat extracted from core GHS to the heat injected into the ground, $R_{e c / r}$, was $10.86 \%$ - see Section 4.5. Thus, the heat, which was extracted from ground and used at higher temperature, divided by heat extracted from ground and used at lower temperature, was about $1 / 4(63.25 / 246.71)$. The total heat supplied 
431 to the user side was $580.63 \mathrm{MW} \cdot \mathrm{h}$. Of this, $306.10 \mathrm{MW} \cdot \mathrm{h}$ was produced by the heat-pump 432 condenser, which accounted for $52.7 \%(306.10 / 580.63) .63 .25 \mathrm{MW} \cdot \mathrm{h}$, which accounted for $10.9 \%(63.25 / 580.63)$, was due to the heat extraction from the core GHS. The remainder of 434 the heat, about $36.4 \%(1-52.7 \%-10.9 \%)$, came from the solar collectors directly. Three measured heat flows were then compared: the heat flow of the user side, the heat flow produced by the heat pump, and the heat flow supplied by the water tanks to the user side. An error of $1.5 \%((580.63-266.00-306.10) / 580.63=1.5 \%)$ was found. It falls within the error described in Section 3.2.

The total electricity consumption of the system in the second recharge/extraction cycle was 124.57 MW'h (65.18 MW'h+59.39 MW'h ). Considering that the total heat supplied to the user side was $580.63 \mathrm{MW} \cdot \mathrm{h}$, the SCOP during the second recharge/extraction cycle was 4.66 (580.63/124.57). The circulation pumps consumed 65.18 MW'h electricity, which was more than half of the total. Fig. 13 shows the percentage of the monthly electricity consumption by the heat pump and circulation pumps. $52.3 \%(65.18 / 124.57)$ of the total electricity was consumed by circulation pumps. $23.8 \%(29.68 / 124.57)$ was consumed during non-heating seasons, while $28.5 \%(52.3 \%-23.8 \%)$ was consumed during the heating season. The heat pump alone consumed $47.7 \%$ (59.39/124.57). Fig. 6 and Fig. 13 show the months, when the heat pump contributed more thermal energy, and it likely consumed more electricity. In Dec 2016 and Feb. 2017, however, the heat produced by the heat pump was almost the same, while the electricity consumption by the heat pump was much higher in Feb. 2017. This is because the $C C O P$ decreased as the heating season continued. The results for the circulation pumps and the heat pump confirm that decreasing the power consumption of the circulation pumps is as important as finding ways to reduce the power consumed by the heat pump. 


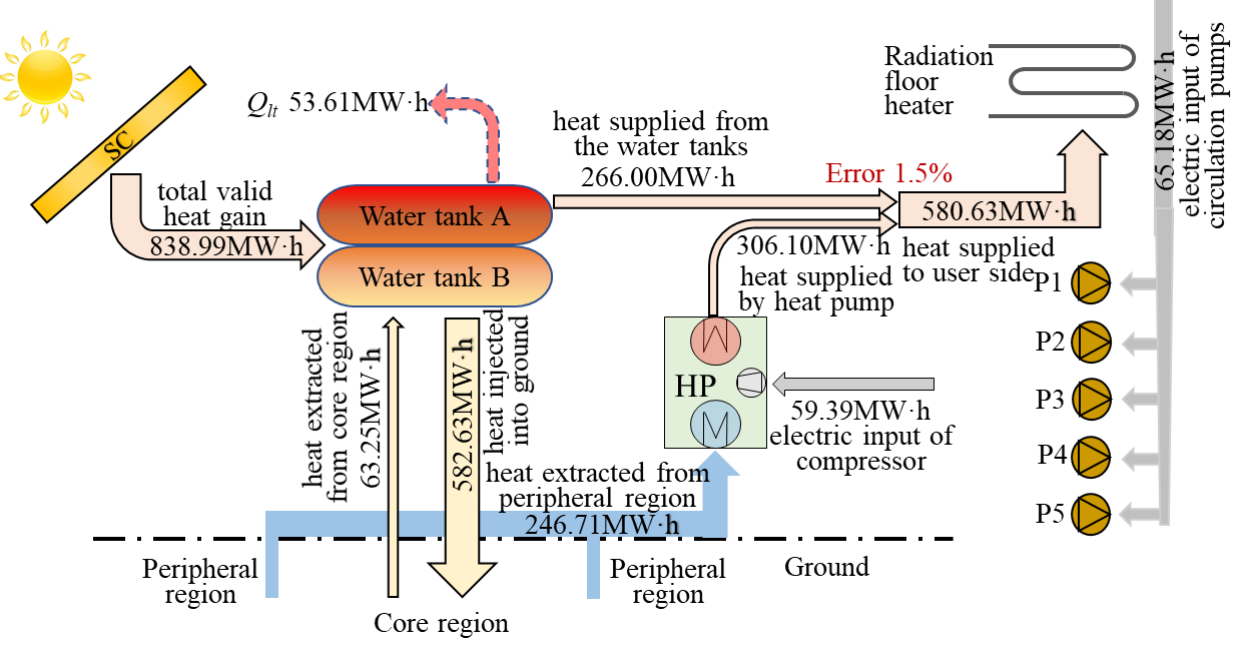

Fig. 12. Energy diagram for the system during the second recharge/extraction cycle

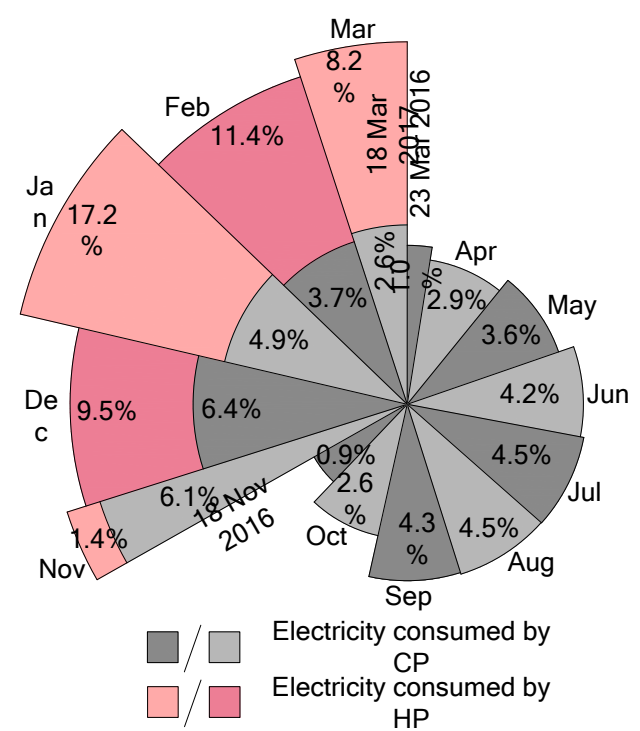

457 Fig. 13. Electricity input distribution of the system during the second recharge/extraction cycle (CP: circulation pump, HP: heat pump)

\section{Discussion}

5.1 SCOP, CCOP, $R_{e c} / r$, and $R_{e t / r}$

461 SCOP represents the overall energy efficiency of the whole hybrid system. A higher SCOP number means that less power is consumed by the system. CCOP, on the other hand, is used to characterize the energy efficiency of the heat pump alone. It is not necessarily true that the hybrid system is capable of reaching a high SCOP when the CCOP is high. $R_{e c / r}$, the ratio of heat extracted from core GHS to the heat injected into the ground, is used to characterize heat 
cascade utilization. A higher $R_{e c / r}$ indicates that a larger proportion of the injected heat is extracted and used at a high temperature. The last parameter $R_{e t / r}$, which is the ratio of the total heat extraction from the ground to the heat injected into it, reflects the energy balance of input and output with respect to the GHS. More heat is injected into the GHS than extracted if $R_{e t / r}$ $<1$, which means the trend of the soil temperature in the GHS is upward. Otherwise, the trend is downward. For this project, a $R_{e t / r}$ of $53.2 \%$ was obtained. The upward trend of the soil temperature in the GHS is shown in Fig. 11.

\subsection{Comparison with previous studies}

The greatest improvement for this hybrid system, compared to previous systems, is the realization of both heat cascade storage and utilization. In most previous studies, the heat produced by solar collectors was evenly injected into the ground, which caused only a small temperature difference between the core and the periphery of the GHS. In the few studies, where a soil temperature gradient was created, the extracted heat from the ground was generally used as heat source for the heat pump, which led to lower system performance (Hesaraki et al., 2015; Wang et al., 2012). In the present study, the test results indicate that the sufficient soil temperature gradient, which is high at the core and low at the periphery, can be created and maintained. About $20 \%$ of the extracted heat from the GHS was used at high temperature and not as heat source for the heat pump. As a result, a higher SCOP of 4.66 was reached, compared with 3.42 in Wang et al. (2012). Even the CCOP for the heat pump is lower than for previous research: 5.15 VS 5.4 (Wang et al., 2012). Despite the lower CCOP for the heat pump, a higher SCOP was attained, thanks to heat cascade storage and utilization.

\subsection{Limitations and suggestions for future studies}

While this new system has been described in detail and was field-tested, which confirmed that it is energy efficient, it should be noted that it is subject to certain limitations and uncertainties: 1) The initial investment costs are high because of the solar-collector purchase and borehole 
491

492

493

494

495

496

497

498

499

500

501

502

503

504

505

506

507

508

509

510

511

512

513

514

drilling. The investigated project was possible and successful due to a subsidy from the government, which supports renewable energy for space heating. This subsidy, however, is only available in selected regions. Therefore, it is generally important to reduce system costs. 2) It is a complex system that consists of many components. Optimally designed components are essential to ensure safe operation, high efficiency, and affordability. The hybrid system may be used in different building types and various climates. However, it is difficult to create a design criterium that would suit every building and all climatic zones. 3) Just as the system design, both control strategy and operating conditions need to be optimized further to improve energy efficiency and reduce cost.

\section{Conclusions}

To maintain the energy quality with high temperature and reduce the energy loss of seasonal heat-storage, a novel SAGSHP system considering heat cascade utilization was introduced and investigated in this study. The installation and field test of the system were conducted in the community Datangfuyuan, China. The system performance was analysed, and the main conclusions can be summarized as follows:

i) The field test shows that the day-averaged indoor temperature can meet the Chinese standard (not fall below $16^{\circ} \mathrm{C}$ ), which shows that the system could satisfy the heating demand successfully.

ii) A high core-temperature and low temperature at the periphery could be implemented and maintained. The month-averaged borehole wall temperature difference between the BHEs, at the core and the periphery, was as high as $30.1^{\circ} \mathrm{C}$. This indicates that heat cascade storage and utilization is practically possible. In addition, the highest month-averaged temperature of the borehole wall in the core increased by $9.9{ }^{\circ} \mathrm{C}$ during the second recharge/extraction cycle, compared to the first recharge/extraction cycle. The upward trend of the soil temperature in the 
core region suggests that higher heat-extraction from the core region may be possible in the

516

517

518

519

520

521

522

523

524

525

526

527

528

529

530

531

532

533

534

535

536

537

538

539 future.

iii) The energy (heat and electricity) balance for the system throughout the second recharge/extraction cycle yields the following performance parameters: $S C O P=4.66$, $C C O P=5.15$. It also shows that $10.9 \%$ of the total heat supplied to the user side comes from the heat extraction from the core region of the GHS. $36.4 \%$ was supplied directly from solar collectors and $52.7 \%$ from the heat pump. In addition, $R_{e t / r}=53.2 \%$ and $R_{e c / r}=10.9 \%$ were obtained for the second recharge/extraction cycle, which shows that more heat was injected into the GHS than extracted. Moreover, the heat, which was extracted from the ground and used at high temperature, divided by the heat extracted from the ground and used at low temperature, was about $1 / 4$.

\section{Acknowledgement}

This research was supported by the National Key Basic Research Program for Youth (No. 2016YFC0207800), the National Natural Science Foundation of China (No. 51408457), and the State Scholarship Fund awarded by China Scholarship Council (No. 201807835013).

\section{References}

Andrew, D., Chiason, P.E., Cen, Y., 2003. Assessment of the viability of hybrid geothermal heat pump systems with solar thermal collectors, ASHRAE Tans. 109, 487-500.

Bauer, D., Marx, R., Nußbicker-Lux, J., Ochs, F., Heidemann, W., Muller-Steinhagen, H., 2010. German central solar heating plants with seasonal heat storage, Sol. Energy 84, 612-623.

Bi, Y.H., Guo, T., Zhang, L., Chen, L., 2004. Solar and ground source heat-pump system, Appl. Energy 78, 231-245.

Chen, X., Yang, H., 2012. Performance analysis of a proposed solar assisted ground coupled heat pump system, Appl. Energy 97, 888-896. 
Cimmino, M., Eslami-Nejad, P., 2017. A simulation model for solar assisted shallow ground heat exchangers in series arrangement, Energy Build. 157, 227-246.

Dai, L., Li, S., DuanMu, L., Li, X., Shang, Y., Dong, M., 2015. Experimental performance analysis of a solar assisted ground source heat pump system under different heating operation modes, Appl. Therm. Eng. 75, 325-333.

Emmi, G., Zarrella, A., Carli, M. D., Galgaro, A., 2015. An analysis of solar assisted ground source heat pumps in cold climates, Energy Convers. Manage. 106, 660-675.

Fine, J.P., Nguyen, H.V., Friedman, J., Leong, W.H., Dworkin, S.B., 2018. A simplified ground thermal response model for analysing solar-assisted ground source heat pump systems, Energy Convers. Manage. 165, 276-290.

Georgiev, A., Popov, R., Toshkov, E., 2018. Investigation of a hybrid system with ground source heat pump and solar collectors: Charging of thermal storages and space heating, Renewable Energy.

Hesaraki, A., Holmberg, S., Haghighat, F., 2015. Seasonal thermal energy storage with heat pumps and low temperatures in building projects-A comparative review, Renew. Sustain. Energy Rev. 43, 1199-1213.

Kandiah, P., Lightstone, M., 2016. Modelling of the thermal performance of a borehole field containing a large buried tank, Geothermics 60, 94-104.

Kjellsson, E., Hellström, G., Perers, B., 2010. Optimization of systems with the combination of ground-source heat pump and solar collectors in dwellings, Energy 35, 2667-2673.

Li, H., Xu, W., Yu, Z., Wu, J., Yu, Z., 2018. Discussion of a combined solar thermal and ground source heat pump system operation strategy for office heating, Energy Build. $162,42-53$.

Liu, L., Zhu, N., Zhao, J., 2016. Thermal equilibrium research of solar seasonal storage system coupling with ground-source heat pump, Energy 99, 83-90. 
Luo, J., Rohn, J., Xiang, W., Bertermann, D., Blum, P., 2016. A review of ground investigations for ground source heat pump (GSHP) systems, Energy Build. 117, 160175

Menergy (Chinese HP manufacturer), <www.menergy.ca/about_us.html>, accessed 08.07.2019

Niemann, P., Schmitz, G., 2019. Experimental investigation of a ground-coupled air conditioning system with desiccant assisted enthalpy recovery during winter mode, Appl. Therm. Eng. 160, 114017

Olsson, S., 1984. The Sunclay and Kullavik Projects - Heat Storage in Clay at Low and High Temperature, First E.C. Conference on Solar Heating. 894-898.

Pinel, P., Cruickshank, C., Beausoleil-Morrison, I., Wills, A., 2011. A review of available methods for seasonal storage of solar thermal energy in residential applications, Renew. and Sustain. Energy Rev. 15, 3341-3359

Rad, F.M., Fung, A.S., Leong, W.H., 2013. Feasibility of combined solar thermal and ground source heat pump systems in cold climate, Canada, Energy Build. 61, 224-232.

Razavi, S.H., Ahmadi, R., Zahedi, A., 2018. Modelling, simulation and dynamic control of solar assisted ground source heat pump to provide heating load and DHW, Appl. Therm. Eng. 129, 127-144.

Reda, F., 2015. Long term performance of different SAGSHP solutions for residential energy supply in Finland, Appl. Energy 144, 31-50.

Sarbu, I., Sebarchievici, C., 2014. General review of ground-source heat pump systems for heating and cooling of buildings, Energy build. 70, 441-454

Shah, S.K., Aye, L., Rismanchi, B., 2018. Seasonal thermal energy storage system for cold climate zones: A review of recent developments, Renew. and Sustain. Energy Rev. 97, $38-49$ 
590

591

592

593

594

595

596

597

598

599

600

601

602

603

604

605

606

607

608

609

610

611

612

613

Si, Q., Okumiya, M., Zhang, X., 2014. Performance evaluation and optimization of a novel solar-ground source heat pump system, Energy Build. 70, 237-245.

Stojanović, B., Akander, J., 2010. Build-up and long-term performance test of a full-scale solar-assisted heat pump system for residential heating in Nordic climatic conditions, Appl. Therm. Eng. 30, 188-195.

Trillat-Berdal, V., Souyri, B., Fraisse, G., 2006. Experimental study of a ground-coupled heat pump combined with thermal solar collectors, Energy Build. 38, 1477-1484.

Verma, V., Murugesan, K., 2017. Experimental study of solar energy storage and space heating using solar assisted ground source heat pump system for Indian climatic conditions, Energy Build. 139, 569-577.Wang, E., Fung, A.S., Qi, C., Leong, W.H., 2012. Performance prediction of a hybrid solar ground-source heat pump system, Energy Build. 47, 600-611.

Wang, X., Zheng, M., Zhang, W., Zhang, S., Yang, T., 2010. Experimental study of a solarassisted ground-coupled heat pump system with solar seasonal thermal storage in severe cold areas, Energy Build. 42, 2104-2110.

Weeratunge, H., Narsilio, G., Hoog, J., Dunstall, S., 2018. Model predictive control for a solar assisted ground source heat pump system, Energy 152, 974-984

Xi, C., Lin, L., Hongxing, Y., 2011. Long term operation of a solar assisted ground coupled heat pump system for space heating and domestic hot water, Energy Build. 43, 18351844.

Xi, J., Li, Y., Liu, M., Wang, R.Z., 2017. Study on the thermal effect of the ground heat exchanger of GSHP in the eastern China area, Energy 141, 56-65.

Xu, J., Wang, R., Li, Y., 2014. A review of available technologies for seasonal thermal energy storage, Sol. Energy 103, 610-638. 
614 Xu, W., Zou, Y., Xu, H.Q., et al., 2012a. Design code for heating ventilation and air 615 conditioning of civil buildings GB 50736-2012, Ministry of Housing and Urban-Rural 616 Development of the PRC.

617 Xu, W., Zou, Y., Wan, S.E., et al., 2012b. Technical specification for radiant heating and 618 cooling JGJ 142-2012, Ministry of Housing and Urban-Rural Development of the PRC.

619 Yang, W., Sun, L., Chen, Y., 2015. Experimental investigations of the performance of a 620 solar-ground source heat pump system operated in heating modes, Energy Build. 89,

621 $97-111$.

622 Yang, W.B., Shi, M.H., Dong, H., 2006, Numerical simulation of the performance of a solar623 earth source heat pump system, Appl. Therm. Eng. 26, 2367-2376.

624 You, T. Li, X., Cao, S., Yang, H., 2018. Soil thermal imbalance of ground source heat pump 625 systems with spiral-coil energy pile groups under seepage conditions and various

626 influential factors, Energy Conversion and Management 178, 123-136

627 Yuan, Y., Cao, X., Sun, L., Lei, B., Yu, N., 2012. Ground source heat pump system: A 628 review of simulation in China, Renewable and Sustainable Energy Reviews 16, 68146822

630

631

Zhu, N., Wang, J., Liu, L., 2015. Performance evaluation before and after solar seasonal storage coupled with ground source heat pump, Energy Convers. Manage. 103, 924-

632 933. 